
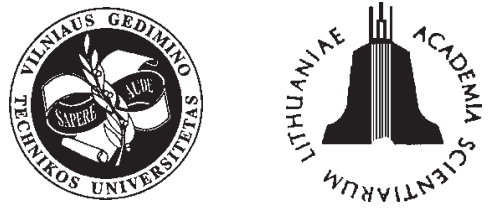

\title{
LARGE VOLUME BUILDINGS: CALCULATIONS OF HEAT LOSSES DUE TO CONDUCTION
}

\author{
Iwona Polarczyk, Pawel Malinowski \\ Technical University of Wroclaw, Institute of Air-Conditioning and District Heating, 4/6 Norwida Str, \\ 50-370 Wroclaw, Poland. E-mail: iwona.polarczyk@pwr.wroc.pl
}

Received 20 April 2005; accepted 21 Dec 2005

\begin{abstract}
The paper covers the questions associated with heating of large-volume buildings using gas-fired air heaters. Particular attention is given to horizontal and vertical distribution of interior temperatures. The problems of temperature gradient impact on calculation of conduction heat losses are discussed.
\end{abstract}

Keywords: heating, energy, large volume buildings.

\section{Introduction}

The major problem encountered when calculating the conduction heat losses is the lack of information required for determining the vertical temperature gradient. According to the Polish standards and their drafts, the room height effect on calculation of conduction heat losses is considered only for buildings that are more than $4 \mathrm{~m}$ high, assuming the vertical temperature gradient value $\beta=0,75^{\circ} \mathrm{C} / \mathrm{m}$ in case of air heating $[1,2]$. According to the German standard, however, the height effect is taken into account by adding 1 to $4{ }^{\circ} \mathrm{C}$ to the value of interior temperature [3, 4]. The German standard does not specify when and which value from this range should be considered in calculations. In the bibliography, other temperature increment values may be found in relation to the room height and applied heating system $[5,6]$.

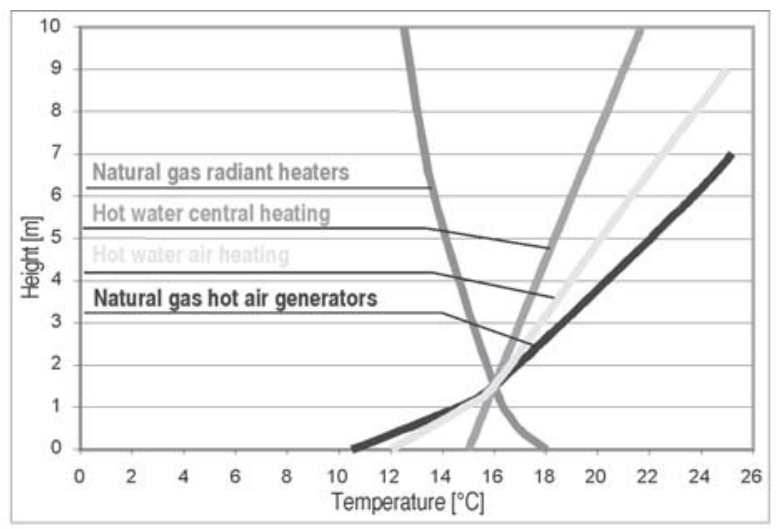

Fig 1. Temperature curves in relation to room height and type of heating equipment [6]
For example, the greatest values of vertical temperature gradient occur when heating rooms with gas-fired hot air generators. As shown in Fig 1, at the room height of $6 \mathrm{~m}$ the increase in temperature is approx $13{ }^{\circ} \mathrm{C}$, which corresponds to the temperature gradient of approx $2,17^{\circ} \mathrm{C} / \mathrm{m}$. However, when analysing Fig 2, at the room height of $6 \mathrm{~m}$ the temperature increase is definitely lower - approx $9{ }^{\circ} \mathrm{C}$, which corresponds to the temperature gradient of approx $1,58{ }^{\circ} \mathrm{C} / \mathrm{m}$.

In some research, conducted by Robur, a producer of gas-fired air heaters, quite different results of temperature distribution were obtained when performing measurements in laboratory [7, 8]. As shown in Fig 3, when heating a $6 \mathrm{~m}$ high room with gas-fired units, they obtained the temperature difference of approx $3{ }^{\circ} \mathrm{C}$, which corresponds to the increase in temperature of approx $0,5^{\circ} \mathrm{C} / \mathrm{m}$.

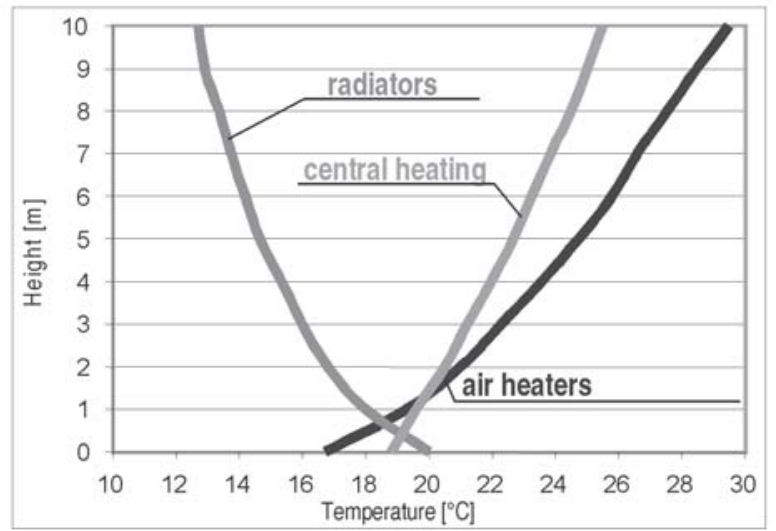

Fig 2. Distribution of room temperature in relation to room height for various heating systems [5] 
Thus, the large-volume building vertical temperature gradient data that are found in standards and other publications are inadequate and different. Now, the question is which values should be assumed when calculating the heat demand?

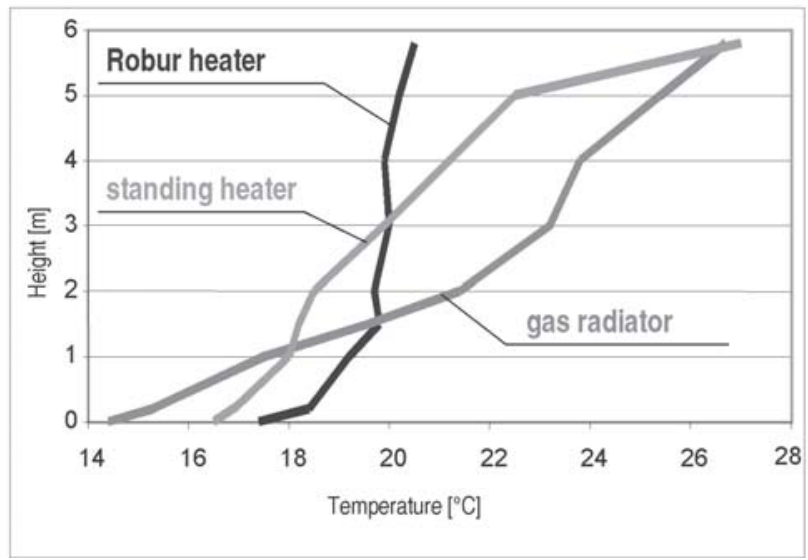

Fig 3. Room temperature curve in relation to room height for various heating systems [8]

\section{Structure and operation of gas-fired air heaters}

Gas-fired air heaters are direct heating and stationary heating devices with a gas burner and air supply ventilator. They are characterised by a large air stream that is forced with a large velocity towards areas occupied by people. An adequately high temperature of the forced air compensates for the undesirable effects associated with such air velocities [9].

Since a number of units can be combined to form a single heating system of unlimited size, such a gas-fired air heating system may be used in an object of any size. By the application of proper control system, it is possible to select the defined heating zones in any time frames.

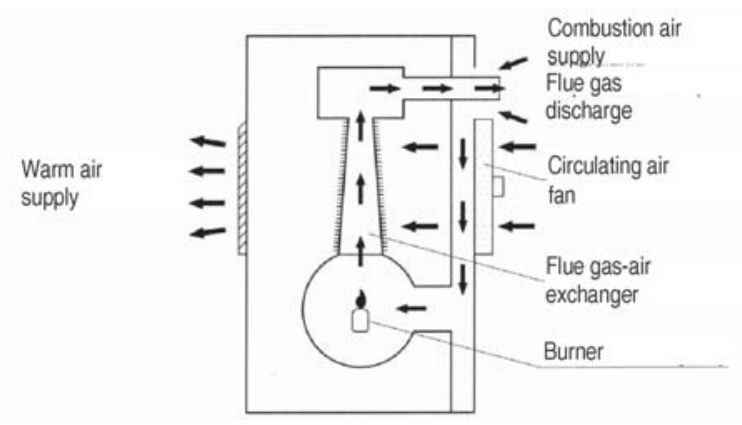

Fig 4. Diagram of gas-fired air heater [9]

The gas-fired air heater gives up the heat to the environment by forced convection. The heater shown in Fig 4 has a flue gas-air type diaphragm heat exchanger. The burner is accommodated for natural or liquefied gas combustion. The combustion air supply and flue gas discharge is by separate forced circulation. As both the combustion chamber and heat exchanger are tight, flue gas is not supplied to the room. The air needed for combustion is supplied to the combustion chamber as a result of negative pressure created by the flue gas discharge fan. It is sucked in from the room or possibly from outside. Flue gas is discharged to the outside through an external wall or up above the roof [9].

Heated air is distributed within the room with the use of ventilator. The heater is accommodated for use with room thermostat or possibly any other room air temperature control system.

The heaters are installed at a height of 2,5-3,5 m above the floor, on a bracket attached to the wall; the thermostat is at the height of approx $2 \mathrm{~m}$.

When the exchanger reaches an adequate temperature, the fan thermostat engages the circulating air fan. When the desired air temperature in the room is obtained, gas flow to the burner is shut and flue gas discharge fan is switched off. The air supply ventilator is on until heat is given up by the exchanger.

By proper setting of vertical and horizontal louvers in the air supply module, it is possible to adjust the range and distribution of air stream inside the building.

The heaters may also be used in summertime to increase air circulation, which causes the feeling of coolness. For this purpose only the ventilator is used in summer and the heater is turned off.

\section{Floor effect}

In large volume buildings, especially in high buildings with typical heating systems, the phenomenon of large vertical temperature gradient may occur, causing:

- an increased infiltration of the outside air into the area occupied by people due to the pressure difference between air layers in the room,

- difficulties in heating the areas occupied by people due to the upward movement of warm air.

According to the manufacturers, the structure of the most recent gas-fired heaters and their heat exchanger shape allow for the so-called "floor effect", also known as "Venturi effect" in order to avoid the large vertical temperature gradient [8]. The air supplied by the heater consists of two layers: basic layer of air heated by the heat exchanger and additional layer of unheated air supplied above the basic layer. As a result of the difference in density between both layers, the warm air is directed toward the floor. The external horizontal lamellas of heat exchanger and uniform temperature distribution its external surface prevent turbulent air movement in the basic layer and consequently preclude air mixing between the basic and additional layers. There is a fear, however, that from time to time this effect may decay between consecutive cycles of heater operation.

\section{Study performed in real objects in France}

Given below are interior vertical temperature distribution results from the study performed in three objects 
Table 1. General characteristics of buildings in France [10]

\begin{tabular}{|c|c|c|c|c|c|}
\hline \multicolumn{2}{|l|}{ Object name } & \multirow{2}{*}{$\begin{array}{c}\text { Building A } \\
\text { SAPEC } \\
\text { Trade centre }\end{array}$} & \multicolumn{2}{|c|}{ Building B MODLING } & \multirow{2}{*}{$\begin{array}{c}\text { Building C } \\
\text { DEHIMI } \\
\text { Industrial plant }\end{array}$} \\
\hline Purpose of building & & & Warehouse & Manufacture & \\
\hline Place & & Beauvais & Moult-Caen & Moult-Caen & Gonesnou \\
\hline Area & $\mathrm{m}^{2}$ & 23550 & 6000 & 10800 & 3000 \\
\hline Maximum height & $\mathrm{m}$ & 9 & 10,5 & 7,5 & 8,5 \\
\hline Volume & $\mathrm{m}^{3}$ & 211950 & 63000 & 81000 & 25500 \\
\hline Installed power & $\mathrm{kW}$ & 2509,2 & 487,9 & 1115,2 & 418,2 \\
\hline Number of units & No & 36 & 7 & 16 & 6 \\
\hline Interior temperature & ${ }^{\circ} \mathrm{C}$ & 17 & 10 & 20 & 17 \\
\hline Exterior temperature & ${ }^{\circ} \mathrm{C}$ & 0 & 0 & 0 & 0 \\
\hline Minimum temperature gradient & ${ }^{\circ} \mathrm{C} / \mathrm{m}$ & 0,45 & 0,38 & 0,32 & 0,71 \\
\hline Maximum temperature gradient & ${ }^{\circ} \mathrm{C} / \mathrm{m}$ & 0,60 & 0,70 & 0,37 & 0,71 \\
\hline
\end{tabular}

located within France [10]. In Table 1, general characteristics of tested objects are presented along with temperature increment measurement results. In Figs 4-7, diagrams and graphs of average vertical temperature gradients are shown as obtained in the French industrial and commercial buildings tested.

\section{Studies performed in real objects in Poland}

In recent years in Poland, interior temperature distribution studies have been performed in connection with the studies of heat comfort in commercial and industrial buildings heated by gas-fired units. Five buildings were selected for testing within the area of city Wrocław and its environs (Table 2). In the period of measurements and about one week before they started, the exterior temperature was around $0{ }^{\circ} \mathrm{C}$, and it was close to the average temperature of heating season for the city [9]. The measurements were carried out after the room interior temperature had set up on the desired level. Thus, the measurements were assumed to have been performed in the settled conditions in respect of exterior and interior temperatures. After performing the measurements and calculations, some interesting conclusions have been formulated [9].

\section{Measurement technique}

Heat flow lost due to the conduction through the building envelope is a function of building geometric and thermal parameters as well as the difference between interior and exterior temperatures. For a given existing object, geometric and thermal parameters are known and stable. However, the exterior and interior air temperature and its distribution are not known. These values were to be determined through measurements performed in the tested buildings in the aspect of their heat demand due to conduction losses.

In order to determine the interior air temperatures and their distribution, a set of copper-constantan thermocouples was used. Particular sensors transmitted their readings to the measurement station from where they were sent to the computer. The measurement was performed continuously and could be observed on the display monitor. It was possible to set the measurement time and temperature value recording intervals. The temperature measurement was performed from the floor level up every $1 \mathrm{~m}$. The equipment resolution accuracy was $0,1^{\circ} \mathrm{C}$. The measurement of exterior air temperature was taken with the use of laboratory mercurial thermometer at $2 \mathrm{~m}$ above the ground level, $5 \mathrm{~m}$ away of an object. This thermometer resolution accuracy was $0,1^{\circ} \mathrm{C}$ [9].

\section{Data obtained and calculations}

In Fig 8, an example building layout is presented and the summary graph of temperature increments in the building in relation to height.

On the basis of data obtained from measurements, interior temperature distributions were determined in relation to height of each measuring point in each building. Next, interior temperature increments were calculated in relation to height and room set temperature (maintained by thermostat). Also, average height-related temperatures were determined as well as average vertical temperature gradients [9].

Interior temperature increments $\Delta T_{z}$ in relation to the set temperature maintained in the building were determined by the formula [9]:

$$
\Delta T_{z}=T_{i}-T_{w} \text {, for } i=0 \text { to } n,
$$

where: $T_{i}$ - temperature at height $i,{ }^{\circ} \mathrm{C}$,

$T_{w}$ - interior set temperature, ${ }^{\circ} \mathrm{C}$.

Average interior temperature gradients were determined by the formula [9]:

$$
\Delta T_{\hat{s} r}=\frac{\sum_{i=1}^{n} \frac{T_{i}-T_{0}}{l_{i}-l_{0}}}{n},
$$

where: $T_{i}$ - temperature at height $i,{ }^{\circ} \mathrm{C}$,

$T_{0}$ - temperature at height $0,{ }^{\circ} \mathrm{C}$. 

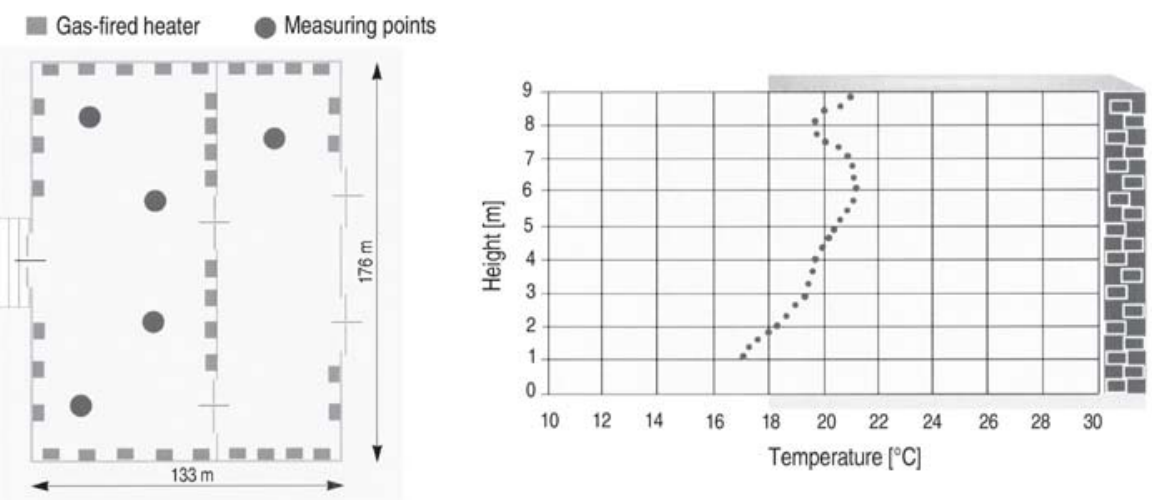

Fig 5. Room layout and average vertical temperature distribution in SAPEC object [10]
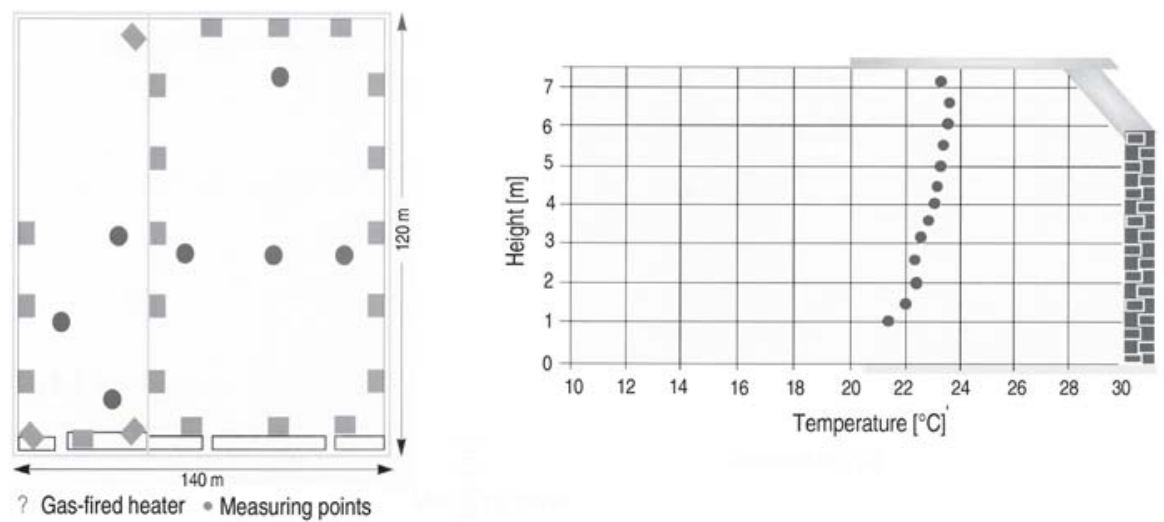

Fig 6. Room layout and average vertical temperature distribution in MODLING object [10]
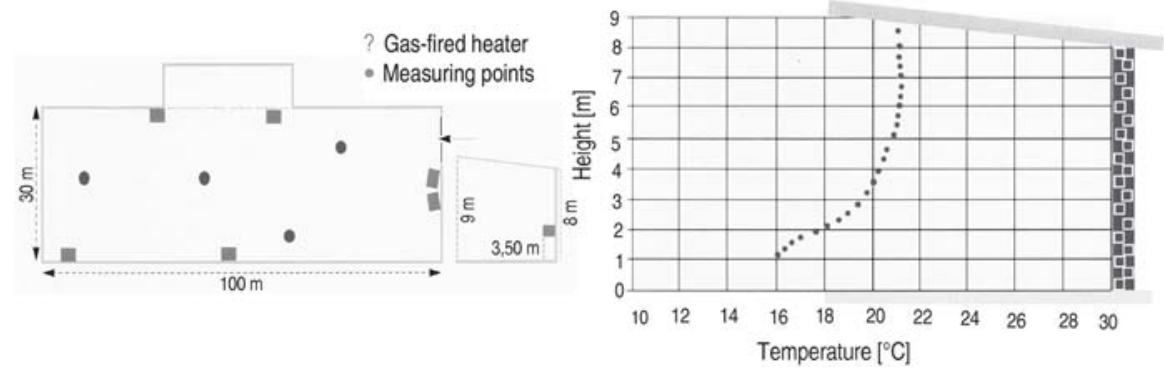

Fig 7. Room layout and average vertical temperature distribution in DEHIMI object [10]

Table 2. Basic parameters of objects tested [9]

\begin{tabular}{l|c|c|c|c|c|c}
\hline \multicolumn{2}{c|}{ Name of object } & Machine Plant & Beauty Centre & Gaja & $\begin{array}{c}\text { Perfecta } \\
\text { windows }\end{array}$ & $\begin{array}{c}\text { Perfecta } \\
\text { sewing }\end{array}$ \\
\hline \multicolumn{1}{c|}{ Parameter } & $\begin{array}{c}\text { Unit of } \\
\text { measure }\end{array}$ & $\begin{array}{c}\text { Building } \\
\text { No 1 }\end{array}$ & $\begin{array}{c}\text { Building } \\
\text { No 2 }\end{array}$ & $\begin{array}{c}\text { Building } \\
\text { No 3 }\end{array}$ & $\begin{array}{c}\text { Building } \\
\text { No 4 }\end{array}$ & $\begin{array}{c}\text { Building } \\
\text { No 5 }\end{array}$ \\
\hline Length & $\mathrm{m}$ & 29,2 & 24 & 58 & 22,7 & 18,8 \\
\hline Width & $\mathrm{m}$ & 18,6 & 12 & 42 & 17,7 & 10,4 \\
\hline Minimum height & $\mathrm{m}$ & 4,8 & & 8,7 & 4,6 & \\
\hline Maximum height & $\mathrm{m}$ & 5,7 & & 11,7 & 5,0 & \\
\hline Average height & $\mathrm{m}$ & 5,25 & 4 & 10,2 & 4,8 & 3,85 \\
\hline Volume & $\mathrm{m}^{3}$ & 2851 & 1152 & 24847 & 1929 & 753 \\
\hline Interior set temperature & ${ }^{\circ} \mathrm{C}$ & 16 & 19 & 18 & 16 & 19 \\
\hline Average heat conduction factor $\mathrm{k}_{\mathrm{AV}}$ & $\mathrm{W} /\left(\mathrm{m}^{2} \mathrm{~K}\right)$ & 0,53 & 0,85 & 0,47 & 0,83 & 0,46 \\
\hline
\end{tabular}



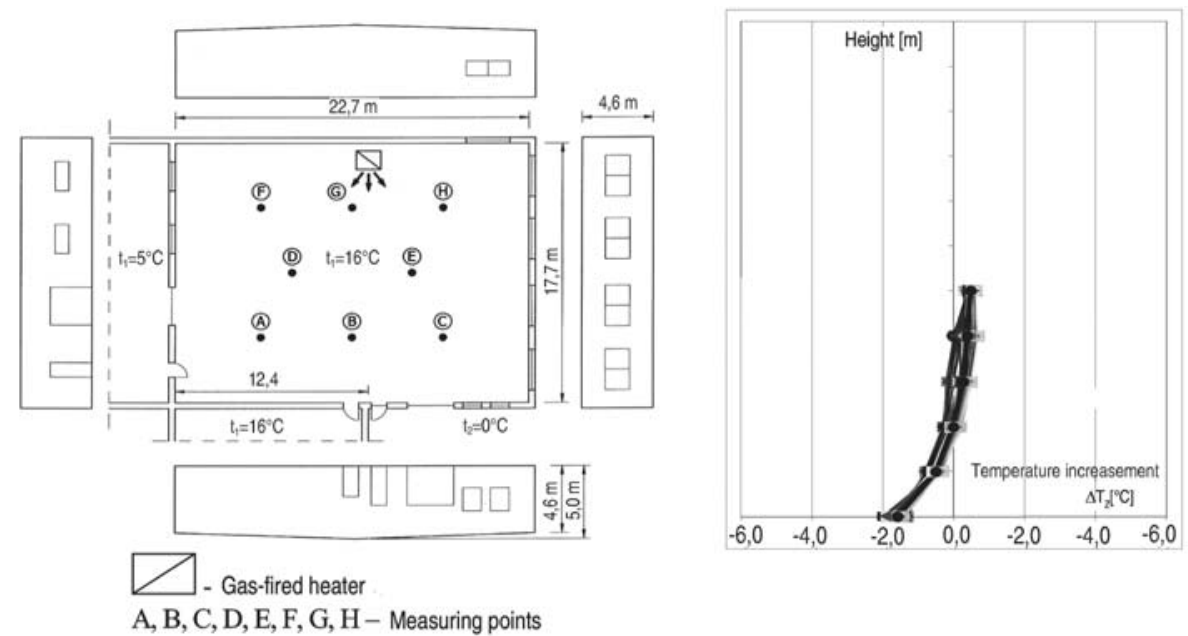

Fig 8. Layout of building No 4 and interior temperature increment in relation to set temperature $t_{i}=16{ }^{\circ} \mathrm{C}$ [9]

\section{Horizontal distribution of interior temperature}

On the basis of calculations, graphs were prepared (Fig 9) showing interior temperature distributions at measuring heights for measuring points. Additionally, average temperature for a given measuring series (black line) was superimposed on each graph. When analysing the graphs, it can be noticed that, irrespective of point location, the temperatures at particular heights change within a very small range, from approx $0,5{ }^{\circ} \mathrm{C}$ to $1^{\circ} \mathrm{C}$. Consequently, average temperatures for those measuring points change very slightly, too [9].

Taking the above into consideration, it was assumed that the horizontal distribution of interior temperatures does not depend on measuring point location, and hence it does not depend on the building layout geometry, as well [9].

\section{Vertical distribution of interior temperature}

On the basis of previous calculations, graphs of interior temperature vertical distributions were also prepared as a function of height in each building and for each measuring points. In Fig 10, there are example graphs for building No 4 . Fig 11 contains graphs of average interior temperature increments in relation to height, and Fig 12, in turn, contains graphs of average interior temperature increment distributions in relation to height and set temperature [9].

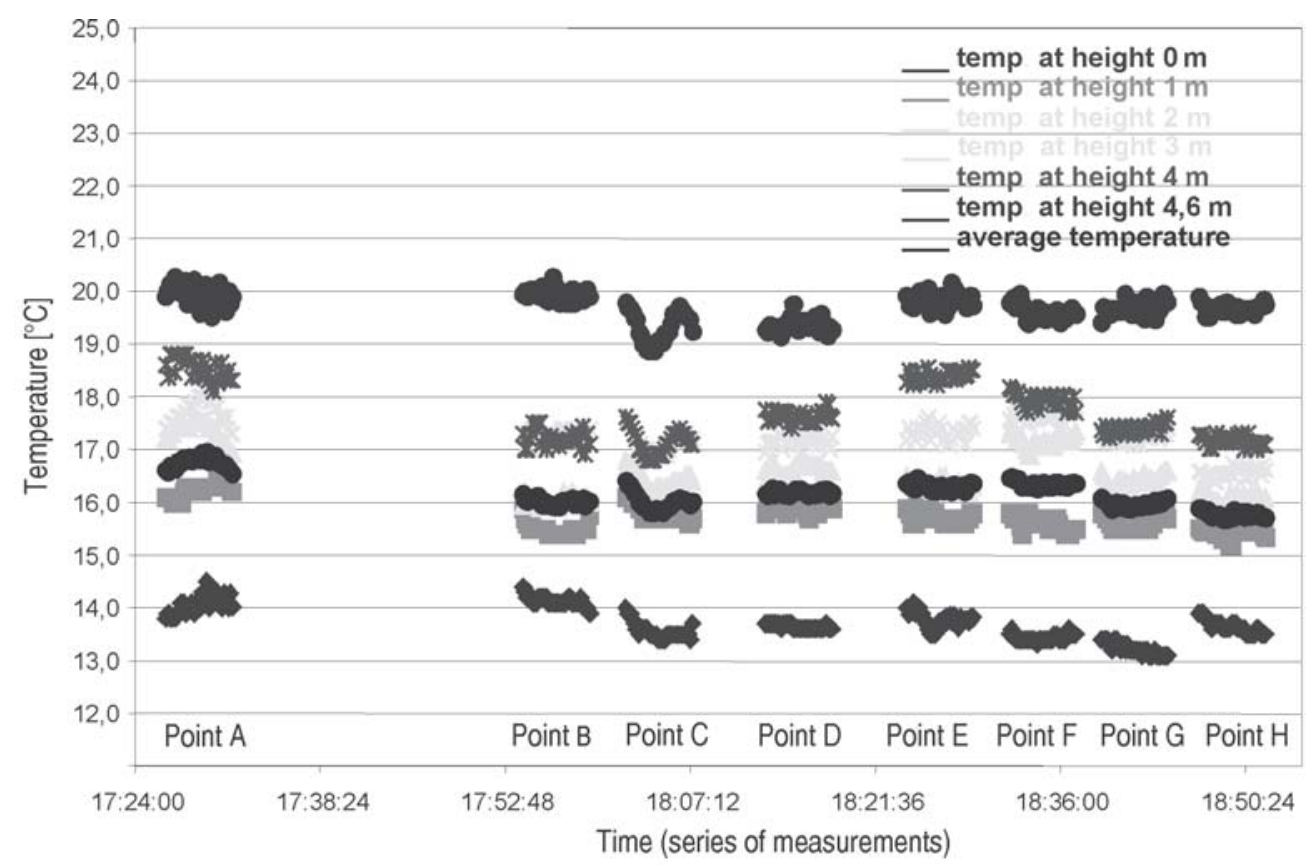

Fig 9. Interior temperature distributions in building No 4 at the heights tested [9] 

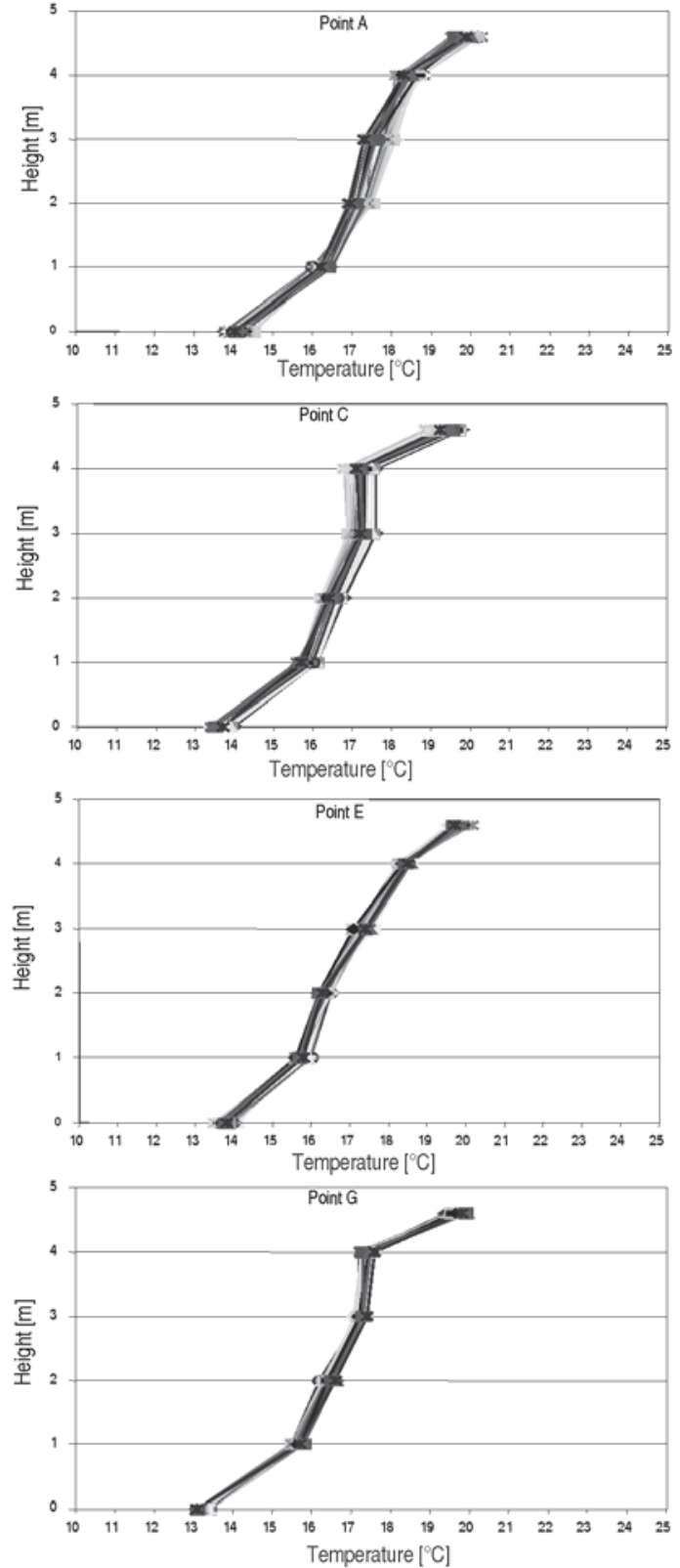
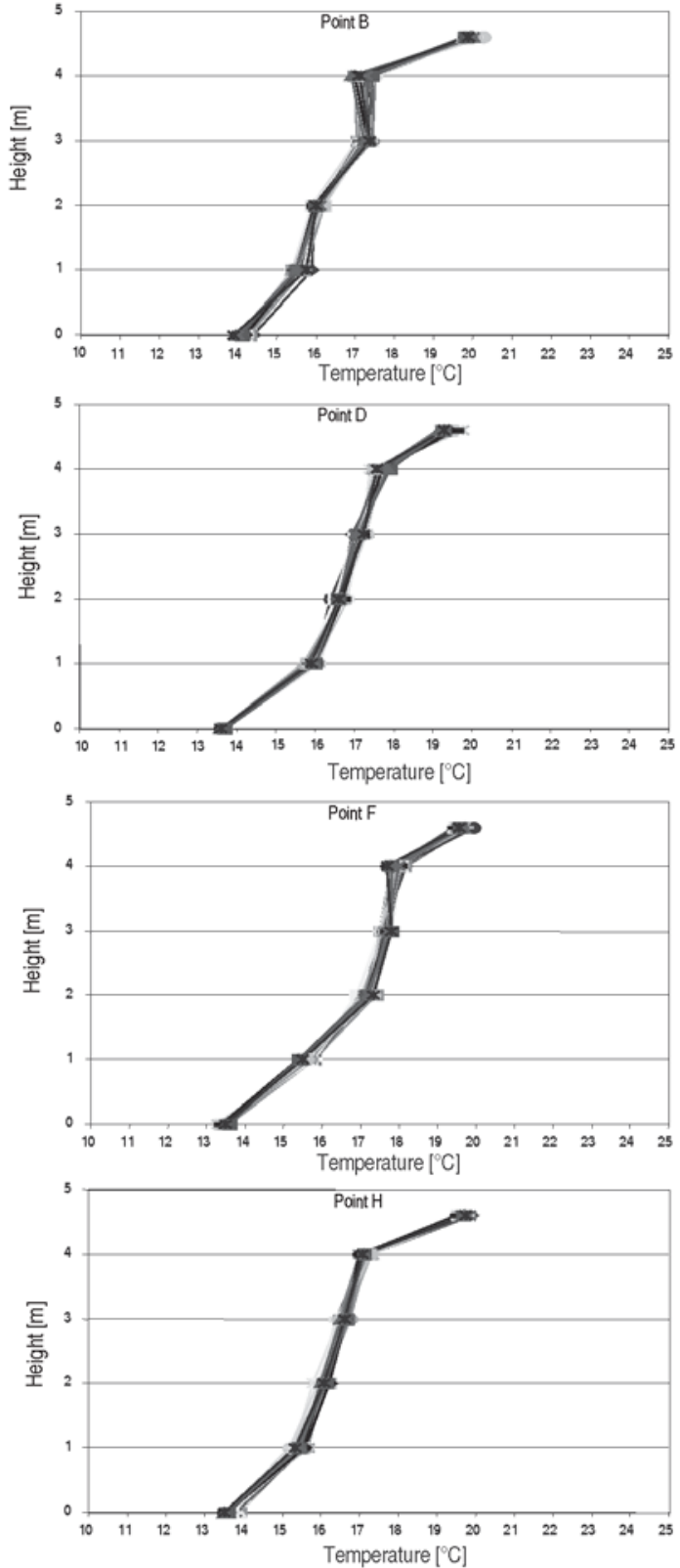

Fig 10. Interior temperature distributions in building No 4 in relation to height [9]

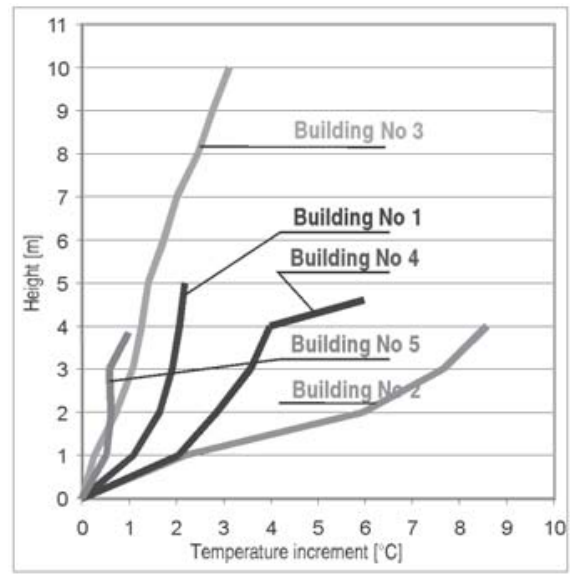

Fig 11. Average interior temperature increments in relation to height [9]

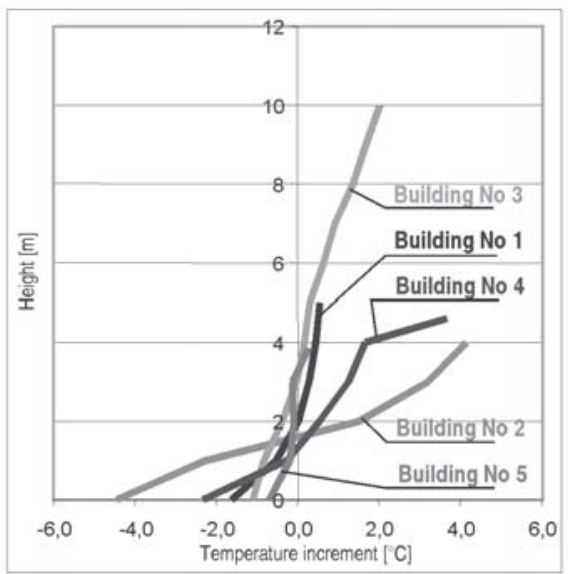

Fig 12. Average interior temperature increment distribution in relation to height and set temperature [9] 
Table 3. Heat demand due to conduction [9]

\begin{tabular}{|c|c|c|c|c|c|c|c|c|c|c|c|c|c|c|c|}
\hline \multirow[b]{2}{*}{$\begin{array}{l}\text { Type of } \\
\text { barrier }\end{array}$} & \multicolumn{5}{|c|}{ BUILDING 1} & \multicolumn{5}{|c|}{ BUILDING 2} & \multicolumn{5}{|c|}{ BUILDING 3} \\
\hline & 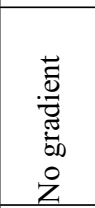 & 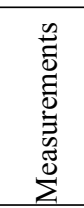 & 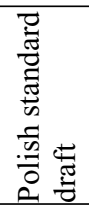 & 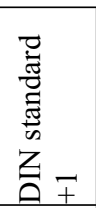 & 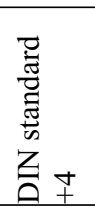 & 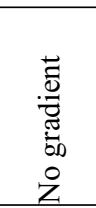 & 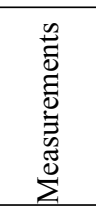 & 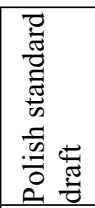 & 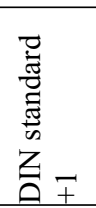 & 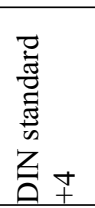 & 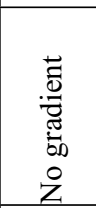 & 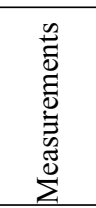 & 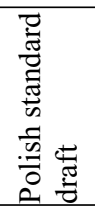 & 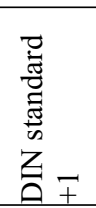 & 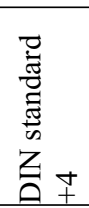 \\
\hline Walls & 5433 & 5424 & 5442 & 5379 & 6327 & 5726 & 5909 & 5726 & 6241 & 7219 & 12292 & 15150 & 12898 & 13581 & 15630 \\
\hline Ceiling & 1878 & 1933 & 1981 & 1857 & 2184 & 3742 & 4580 & 3742 & 4090 & 4703 & 31078 & 34531 & 39106 & 32804 & 37984 \\
\hline Floor & 2183 & 1835 & 2183 & 2341 & 2992 & 2564 & 1649 & 2564 & 2798 & 3422 & 7055 & 6377 & 7055 & 7672 & 9523 \\
\hline Total & 9494 & 9192 & 9606 & 9679 & 11606 & 12032 & 12138 & 12032 & 13129 & 15344 & 50425 & 56058 & 59059 & 54057 & 63137 \\
\hline Total, $\%$ & $100 \%$ & $97 \%$ & $101 \%$ & $102 \%$ & $122 \%$ & $100 \%$ & $101 \%$ & $100 \%$ & $109 \%$ & $128 \%$ & $100 \%$ & $111 \%$ & $117 \%$ & $107 \%$ & $125 \%$ \\
\hline
\end{tabular}

\begin{tabular}{|c|c|c|c|c|c|c|c|c|c|c|}
\hline \multirow[b]{2}{*}{$\begin{array}{l}\text { Type of } \\
\text { barrier }\end{array}$} & \multicolumn{5}{|c|}{ BUILDING 4} & \multicolumn{5}{|c|}{ BUILDING 5} \\
\hline & 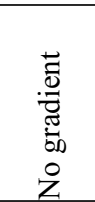 & 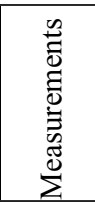 & 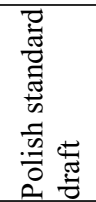 & 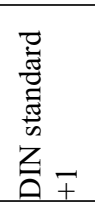 & 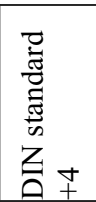 & 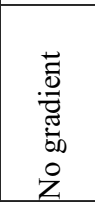 & 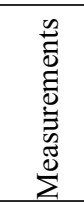 & 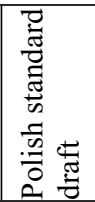 & 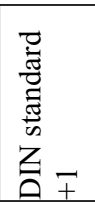 & 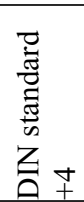 \\
\hline Wal & 5049 & 5275 & 5062 & 5719 & 6813 & 2248 & 2225 & 2248 & 2868 & 3359 \\
\hline Ceil & 251 & 5306 & 4422 & 4850 & 5705 & 1295 & 1317 & 1295 & 1447 & 1664 \\
\hline Floor & 004 & 909 & 2004 & 2261 & 2934 & 1018 & 961 & 1018 & 1118 & 1367 \\
\hline Tota & 11304 & \begin{tabular}{|l|}
11490 \\
\end{tabular} & 11488 & 12830 & 15452 & 4561 & 4503 & 4561 & 5433 & 6390 \\
\hline Total, $\%$ & $100 \%$ & $102 \%$ & $102 \%$ & $113 \%$ & $137 \%$ & $100 \%$ & $99 \%$ & $100 \%$ & $119 \%$ & $140 \%$ \\
\hline
\end{tabular}

From Fig 11 that shows how temperature changes with height, the impression may be gained that, for example, if an object is improperly insulated, then, when calculating heat demand, a considerable warm air convection effect should be taken into account. However, when analysing this problem in relation to the set temperature, it should be noticed that temperature changes are uniformly distributed around that temperature (Fig 12). The changes begin from the floor level, where temperature is definitely lower than the set temperature, and they increase in the roof direction [9].

\section{Summary}

In order to determine the impact of internal temperature increase on heat losses due to conduction, heat demand calculations were performed in the following five variants:

1) according to draft standard PrPN-B-03405 with gradient $\beta=0,75^{\circ} \mathrm{C} / \mathrm{m}$,

2) according to measurement results obtained,

3) without taking internal temperature gradient into account,

4) according to DIN 4701 standard with taking into account internal temperature increase by $1{ }^{\circ} \mathrm{C}$,

5) according to DIN 4701 standard with taking into account internal temperature increase by $4{ }^{\circ} \mathrm{C}$, with their results presented in Table 3.

When comparing these results, in respect of heat demand calculations without taking the gradient into account, it follows that the largest differences in heat loss values occur in case of calculations according to the DIN standard. Also, in case of calculations performed on the basis of measurement results, the differences are up to tens percent, especially in case of increasing internal temperature by $4{ }^{\circ} \mathrm{C}$.

\section{Conclusions}

From the analysis of temperature change graphs it follows that below the level of thermostat there is a minus gradient of temperature in relation to the set temperature. Therefore, in this zone the heat losses should be lower than those calculated as the temperature is lower than the calculated interior temperature. This might be considered as a possible compensation for the heat losses resulting from elevated (due to the gradient) temperatures in the upper zone, and consequently possible omission of temperature increment when calculating heat losses.

When calculating transmission heat losses, on the basis of data obtained from measurements and without taking into account the temperature increment, the largest difference in results, nearly $11 \%$, was obtained for Building No 3, which was, at the same time, the highest and the largest in volume of all tested buildings. But when comparing the absolute values for that case, the maximum difference is approx $5,5 \mathrm{~kW}$. In other cases, the difference ranges from $1 \div 3 \%$. For further research it would be very good to include also the results obtain from the study of external air infiltration influence on the heat demand for such buildings. Although the newly constructed large volume buildings are usually very good isolated and hermetic.

It may then be assumed that when calculating the conduction heat demand for building in which heaters are used, there is no need to consider the interior tem- 
perature vertical gradient. This may be additionally supported by the fact that for such types of buildings the decisive part in total heat demand comes from ventilation needs which may be several times higher than infiltration heat losses.

These studies, which were part of a research project, demonstrated among the other things that it is possible to considerably reduce the vertical increment of interior air temperature in large-volume buildings. In buildings where there is a high vertical temperature gradient with traditional heating systems, it is possible to reduce it to practically negligible values, but only with the application of modern heating systems. This may bring measurable economic effects while maintaining heat comfort for people [11].

\section{References}

1. PN-B-02020. Polish National Standard Code - Thermal protection of buildings. Requirements and calculations (Ochrona cieplna budynków. Wymagania i obliczenia). Warsaw, 1991. 22 p. (in Polish).

2. PrPN-B-03405. Polish National Standard Code - Heating. Calculation of heat losses of rooms over $600 \mathrm{~m}^{3}$ (Ogrzewnictwo. Obliczanie zapotrzebowania ciepła pomieszczeń o kubaturze ponad $600 \mathrm{~m}^{3}$ ). Warsaw, 1979. 5 p. (in Polish).

3. DIN 4701. Calculation of heat losses of buildings. Standards of calculations. Part 1. (Regeln für die Berechnung des Wärmebedarfs von Gebäuden. Grundanlagen der Berechnung. Teil 1). Berlin, 1983. 28 p. (in German).

4. DIN 4701. Calculation of heat losses of buildings. Tables, figures and algorithms. Part 2. (Regeln für die Berechnung des Wärmebedarfs von Gebäuden. Tabellen, Bilden, Algorithmen. Teil 2). Berlin, 1983. 22 p. (in German).

5. Bąkowski, K. Heating of industrial spaces and public buildings (Ogrzewanie gazem hal przemysłowych i obiektów użyteczności publicznej). LPG Gaz Plynny, Part 1. Warsaw, 1999, p. 12-17 (in Polish).

6. Kowalczyk, M. Heating of large volume buildings by gasheaters (Ogrzewanie obiektów wielkokubaturowych gazowymi promiennikami podczerwieni). Gdańsk, 1997. 230 p. (in Polish).

7. Boschi, D. Negative aspects of radiation heating (Die Strahlungsheizung: nachweisbare negative Aspekte). Zingonia, 1997. 10 p. (in German).

8. Robur - Archimede Test Laboratory. Zingonia, 1997. 18 p. (in German).

9. Polarczyk, I. Research on thermal comfort in industrial spaces heated by gas-fired heaters (Badania komfortu cieplnego $\mathrm{w}$ halach $\mathrm{z}$ gazowymi nagrzewnicami powietrza). PhD dissertation. Wrocław University of Technology, 2002. 152 p. (in Polish).

10. Robur - Results of measurements in buildings located in France. Zingonia, 1997. 10 p. (in German).

11. PN-EN ISO 7726:2002. Thermal environments - instruments and methods for measuring physical quantities. (Ergonomia środowiska termicznego. Przyrządy do pomiaru wielkości fizycznych). Warsaw, 2002. 54 p. (in Polish).

\section{DIDELIO TŪRIO PASTATAI IR NUOSTOLIŲ DĖL ŠILUMOS LAIDUMO SKAIČIAVIMAS}

\section{Polarczyk, P. Malinowski}

Santrauka

Šiame darbe nagrinejjami klausimai, susiję su didelio tūrio pastatų šildymu naudojant dujinius oro šildytuvus. Pagrindinis dèmesys sutelktas į horizontaluji ir vertikaluji temperatūrų pasiskirstymą pastate. Darbe aptariamos šilumos nuostolių skaičiavimo problemos, atsirandančios dèl temperatūros gradiento poveikio.

Raktažodžiai: šildymas, energija, didelio tūrio pastatai

Pawel MALINOWSKI. Doctor working since 1991 at the Wrocław University of Technology, Poland. Adjunct at the District Heating and Ventilation Chamber. Teaching subjects: energy, energy systems, natural gas and domestic water systems and instalations, as well as modelling, mathemathical modelling, data analysis, control systems. Research in different domains such as optimisation of energy systems, analysis of monitoring data, neural networks and fuzzy logic models of air-pollutants movment. Published about 70 papers. Research interest is focused on applying the computer science methods to modelling the energy systems.

Iwona POLARCZYK. Doctor working at the District Heating and Ventilation Chamber of Wrocław University of Technology, Poland. Her PhD in 2002 on heating of big-volume buildings. Her research interest is focused on domestic hot water systems and ventilation and heating of buildings. Author and co-author of about 30 papers in those research areas. 